\title{
Phylogenetic heterogeneity within the genus Herpetosiphon: transfer of the marine species Herpetosiphon cohaerens, Herpetosiphon nigricans and Herpetosiphon persicus to the genus Lewinella gen. nov. in the Flexibacter-Bacteroides-Cytophaga phylum
}

\author{
L. I. Sly, M. Taghavit and M. Fegan
}

Author for correspondence: L. I. Sly. Tel: +6173365 2396. Fax: +61 733651566. e-mail: sly@biosci.uq.edu.au

Centre for Bacterial

Diversity and

Identification,

Department of

Microbiology, The

University of Queensland

Brisbane, Australia 4072

\begin{abstract}
Analysis of the $16 \mathrm{~S}$ rDNA sequences of species currently assigned to the genus Herpetosiphon revealed intrageneric phylogenetic heterogeneity. The thermotolerant freshwater species Herpetosiphon geysericola is most closely related to the type species Herpetosiphon aurantiacus in the Chloroflexus subdivision of the green non-sulfur bacteria. The marine species Herpetosiphon cohaerens, Herpetosiphon nigricans and Herpetosiphon persicus, on the other hand, were found to form a cluster with the sheathed bacterium Haliscomenobacter hydrossis in the Saprospira group of the Flexibacter-Bacteroides-Cytophaga (FBC) phylum. A proposal is made to transfer these marine species to the genus Lewinella gen. nov. as Lewinella cohaerens comb. nov., Lewinella nigricans comb. nov. and Lewinella persica comb. nov. The marine sheathed gliding bacterium Flexithrix dorotheae was also found to be a member of the FBC phylum but on a separate phylogenetic line to the marine herpetosiphons now assigned to the genus Lewinella.
\end{abstract}

Keywords: Herpetosiphon, Lewinella gen. nov., Flexibacter-Bacteroides-Cytophaga phylum

\section{INTRODUCTION}

The genus Herpetosiphon currently contains five species $(25,41)$ of gliding bacteria characterized by the ability to form sheathed filaments $(9,20)$. The genus and the type species Herpetosiphon aurantiacus were first described in 1968 by Holt \& Lewin (10). The genus was assigned to the order Flexibacterales as defined by Soriano \& Lewin (43), and it was considered that $H$. aurantiacus was an apochlorotic counterpart of the cyanobacterium Lyngbya, supported at the time by similar base composition of their DNA (24). In 1970, three new marine species of Herpetosiphon, Herpeto-

\footnotetext{
†Present address: College of Agriculture, Shiraz University, Shiraz, Iran. Abbreviation: FBC, Flexibacter-Bacteroides-Cytophaga.

The GenBank accession numbers for the rDNA sequences of Herpetosiphon geysericola ATCC 23076', Lewinella cohaerens ATCC 23123', Lewinella nigricans ATCC $23147^{\top}$, Lewinella persica ATCC $23167^{\top}$ and Flexithrix dorotheae ATCC $23163^{\top}$ reported in this paper are AF039292-AF039296, respectively.
}

siphon cohaerens, Herpetosiphon nigricans and Herpetosiphon persicus, were described and a fourth species incorrectly classified as the cyanobacterium Phormidium geysericola was transferred to the genus as Herpetosiphon geysericola comb. nov (20). Lewin (19) also described another flexuous gliding ensheathed marine species, Flexithrix dorotheae, which is distinguished by its propensity for false branching and a lower DNA base composition. The DNA base composition of this species was $37.2 \mathrm{~mol} \% \mathrm{G}+\mathrm{C}$, which is well below the $45-53 \mathrm{~mol} \% \mathrm{G}+\mathrm{C}$ range for the species of Herpetosiphon (24). Flexithrix dorotheae and the marine species of Herpetosiphon apparently have not been studied in detail since and very little new information is known about their characteristics. $H$. aurantiacus is known to belong to the Chloroflexus subdivision of the green non-sulfur bacteria $(7,30,50)$ but the intrageneric relationships of the species of Herpetosiphon have been based on phenotypic characteristics $(9,10,20,36)$ and DNA base composition data (24). In this paper we report the determination 
and analysis of the 16S rDNA sequences for the type strains of the species currently assigned to the genus Herpetosiphon, which revealed that the marine species are phylogentically unrelated to the freshwater species, including the type species of the genus, $H$. aurantiacus. Consequently, we propose that these marine species be transferred to the genus Lewinella gen. nov. named in honour of Professor Ralph Lewin who first described these bacteria.

\section{METHODS}

Bacterial cultures. Cultures of Herpetosiphon cohaerens ATCC $23123^{\mathrm{T}}$, Herpetosiphon geysericola ATCC $23076^{\mathrm{T}}$, Herpetosiphon nigricans ATCC $23147^{\mathrm{T}}$, Herpetosiphon persicus ATCC $23167^{\mathrm{T}}$ and Flexithrix dorotheae ATCC $23163^{\mathrm{T}}$ were obtained from the American Type Culture Collection, Rockville, MD, USA.

$16 S$ rDNA sequencing methods. Direct PCR amplification of 16S rDNA was performed as previously described (46). The PCR products were purified using Promega Magic PCR Prep DNA Purification according to the manufacturer's instructions. The PRISM Ready Reaction DyeDeoxy Terminator Cycle Sequencing Kit (Applied Biosystems) was used with the primers 27f, 926f, 1114f, 357r, 519r, 907r, $1100 \mathrm{r}, 1392 \mathrm{r}$ and $1525 \mathrm{r}$ (15) and $787 \mathrm{r}$ and $803 \mathrm{f}$ (44) to directly sequence the PCR products, following the protocol provided by the manufacturer. The reaction mixtures were sequenced automatically on an Applied Biosystems 373A DNA Sequencer.

Data analysis. The $16 \mathrm{~S}$ rDNA sequences were aligned manually using the ae 2 editor with representative bacterial 16S rRNA gene sequences from the RNA Database Project (22) and GenBank. Positions where length and sequence variations made alignment uncertain were omitted from the analysis. Pairwise evolutionary distances were computed using the method of Jukes \& Cantor (13) in the DNADIST program in the PHYLIP $3.5 \mathrm{c}$ software package (5). Phylogenetic dendrograms were constructed using the neighbourjoining method of Saitou \& Nei (40) and by the parsimony method using DNAPARS in PHYLIP. Bootstrap analyses using SEQBOOT PHYLIP 3.5c were performed to determine the statistical significance of branching patterns and consensus trees (not shown) were produced using CONSENSE (PHYLIP 3.5c).

Reference sequence accession numbers and strain numbers (where available) used in the phylogenetic analyses were as follows: Bacteroides fragilis, M61006; Chlorobium vibrioforme DSM $260^{\mathrm{T}}$, M62791; Chloroflexus aurantiacus ATCC 29366 ${ }^{\mathrm{T}}$, M34116; Cyclobacterium marinus ATCC 43824, M62788; Cytophaga diffluens ATCC 23140, M58765; Cytophaga hutchinsonii ATCC 33406 ${ }^{\mathrm{T}}$, M58768; Deinococcus radiodurans ATCC 35073, M21413; Empedobacter brevis ATCC 14234, M59052; Flavobacterium aquatile ATCC

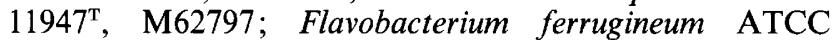
13524', M62798; Flectobacillus major ATCC 29496 ${ }^{\mathrm{T}}$, M62787; Flexibacter aggregans ATCC 23162 ${ }^{\mathrm{T}}$, M64628; Flexibacter canadensis ATCC 29591 ${ }^{\mathrm{T}}$, M62793; Flexibacter litoralis ATCC 23117 ${ }^{\mathrm{T}}$, M58784; Flexibacter roseolus ATCC 23088 ${ }^{\mathrm{T}}$, M58787; Flexibacter ruber ATCC 23103 ${ }^{\mathrm{T}}$, M58788; Flexibacter sancti ATCC 23092 ${ }^{\mathrm{T}}$, M62795; Haliscomenobacter hydrossis ATCC 27775 ${ }^{\mathrm{T}}$, M58790; Herpetosiphon aurantiacus ATCC 23779 ${ }^{\mathrm{T}}$, M34117; Meiothermus ruber ATCC $35948^{\mathrm{T}}$, Z15059; 'Microscilla aggregans subsp. catalatica' ATCC 23190, M58791; 'Microscilla arenaria'
ATCC 23161, M60455; 'Microscilla furvescens', ATCC 23129, M58792; Rhodothermus marinus, X77140; Runella slithyformis ATCC 29530 $0^{\mathrm{T}}$, M62786; Saprospira grandis ATCC 23119 ${ }^{\mathrm{T}}$, M58795; Spirosoma linguale ATCC 23276, M62789; Thermomicrobium roseum ATCC 27502 ${ }^{\mathrm{T}}$, M34115; and Thermonema lapsum, L11703.

\section{RESULTS AND DISCUSSION}

Comparison of the 16S rDNA sequences of the species of Herpetosiphon has revealed phylogenetic heterogeneity within the genus unexpected from previous limited knowledge of their phenotypic and genotypic characteristics. Almost complete $16 \mathrm{~S}$ rDNA sequences ( $>1417$ nucleotides) were obtained for the type strains of the species $H$. cohaerens, $H$. geysericola, $H$.nigricans and $H$. persicus. The $16 \mathrm{~S}$ rDNA sequences were compared with the known sequence available for the type strain of $H$. aurantiacus and other reference sequences required to phylogenetically position the species of Herpetosiphon.

Knowledge of the phylogenetic position of the genus Herpetosiphon has been based on data obtained for the type species $H$. aurantiacus. Evidence obtained from 16S rRNA oligonucleotide catalogues $(7,50)$ and $16 \mathrm{~S}$ rRNA sequences (30) has shown that this species belongs to the green non-sulfur bacteria together with Chloroflexus and Thermomicrobium. This relationship between Herpetosiphon and Chloroflexus is supported by their unusual cell wall composition $(11,12)$. The analysis of the 16S rDNA sequences for the other Herpetosiphon species obtained in the present study showed that the thermotolerant freshwater species $H$. geysericola was phylogenetically related to $H$. aurantiacus in the green non-sulfur phylum, but that the

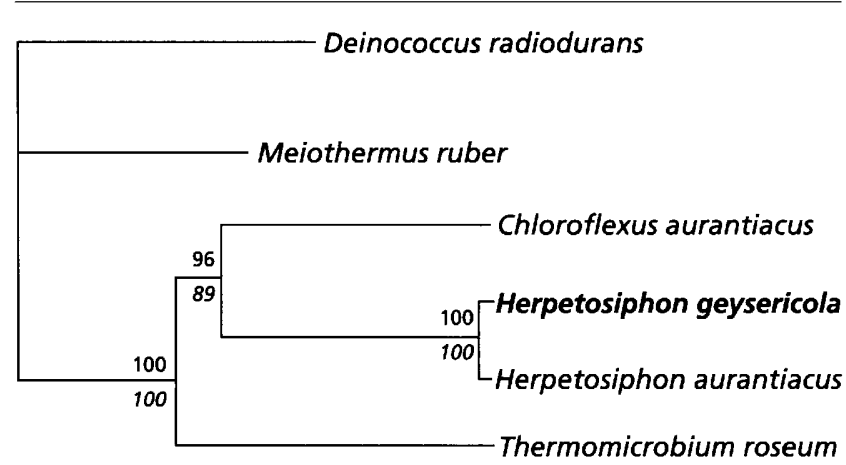

$0 \cdot 1$

Fig. 1. Phylogenetic tree constructed by the neighbour-joining method showing the relationships of species of the genus Herpetosiphon in the green non-sulfur phylum. The sequence of Deinococcus radiodurans was used as the outgroup. Bootstrap values of 100 analyses are shown at the top of the branching points for the neighbour-joining analysis and below (in italics) for the parsimony analysis. The scale bar represents 10 nucleotide substitutions per 100 nucleotides of 16S rDNA sequence. 
three marine species $H$. cohaerens, $H$. nigricans and $H$. persicus belong to the Flexibacter-BacteroidesCytophaga (FBC) phylum.

The dendrogram of relationships (Fig. 1) inferred from a neighbour-joining analysis of the corrected dissimilarity values over a length of 1058 nucleotides indicated that $H$. geysericola is most closely related to $H$. aurantiacus amongst the members of the green nonsulfur bacteria. The sequences of $H$. aurantiacus and $H$. geysericola have a similarity of $96.4 \%$, which is indicative of separate species status $(45,48)$ within the genus. The analysis of the $16 \mathrm{~S}$ rDNA sequence data by the parsimony method produced a phylogenetic tree (not shown) with the same topography as the neighbour-joining tree. Bootstrap values determined from 100 resamplings indicate strong statistical support for the phylogenetic relationships.

For the marine species $H$. cohaerens, $H$. nigricans and $H$. persicus, the dendrogram of relationships (Fig. 2) inferred from a neighbour-joining analysis of the corrected dissimilarity values over a length of 1105 nucleotides showed that these species clustered together in a deep phylogenetic line within the Saprospira group of the FBC phylum. The Saprospira group also includes the non-motile sheathed organism Haliscomenobacter hydrossis $(3,6,47)$. Haliscomenobacter hydrossis is not a marine organism but rather is isolated from sewage treatment plants where it often causes problems with bulking $(3,47)$. The $16 \mathrm{~S}$ rDNA sequences of $H$. cohaerens, $H$. nigricans and $H$. persicus over a length of 1418 nucleotides have similarity values in the range $86-88 \%$, which is clearly indicative of separate species status in spite of the few known phenotypic characteristics which differentiate these species $(9,20,36)$. Bootstrap values provide strong support that the marine Herpetosiphon species form a phylogenetically coherent cluster within the wellsupported Saprospira group (Fig. 2).

The present research findings confirm the taxonomic and phylogenetic relationships of the marine species of the genus Herpetosiphon, but not the type species of the genus, with the flexibacteria, now known to be members of the FBC phylum. These findings emphasize that the characteristics of gliding motility and ensheathed filament formation are not phylogentically discriminative features (39). The phylogenetic position of the genus Herpetosiphon has been a matter of speculation since its description, and at various times these organisms have been considered to be apochlorotic counterparts of the cyanobacteria (10, $20,37)$, Flexibacteriaceae (18), Cytophagaceae $(17,18)$, and currently as a separate genus in the green nonsulfur bacteria (36). Chemotaxonomic determination of sulfonolipids (8) and the absence of flexirubin-like pigments $(14,38)$ refuted a close relationship with the cytophagas. However, these studies have been restricted to the type species $H$. aurantiacus or its synonymous relative 'Herpetosiphon giganteus'. The marine species remain poorly studied and their in-

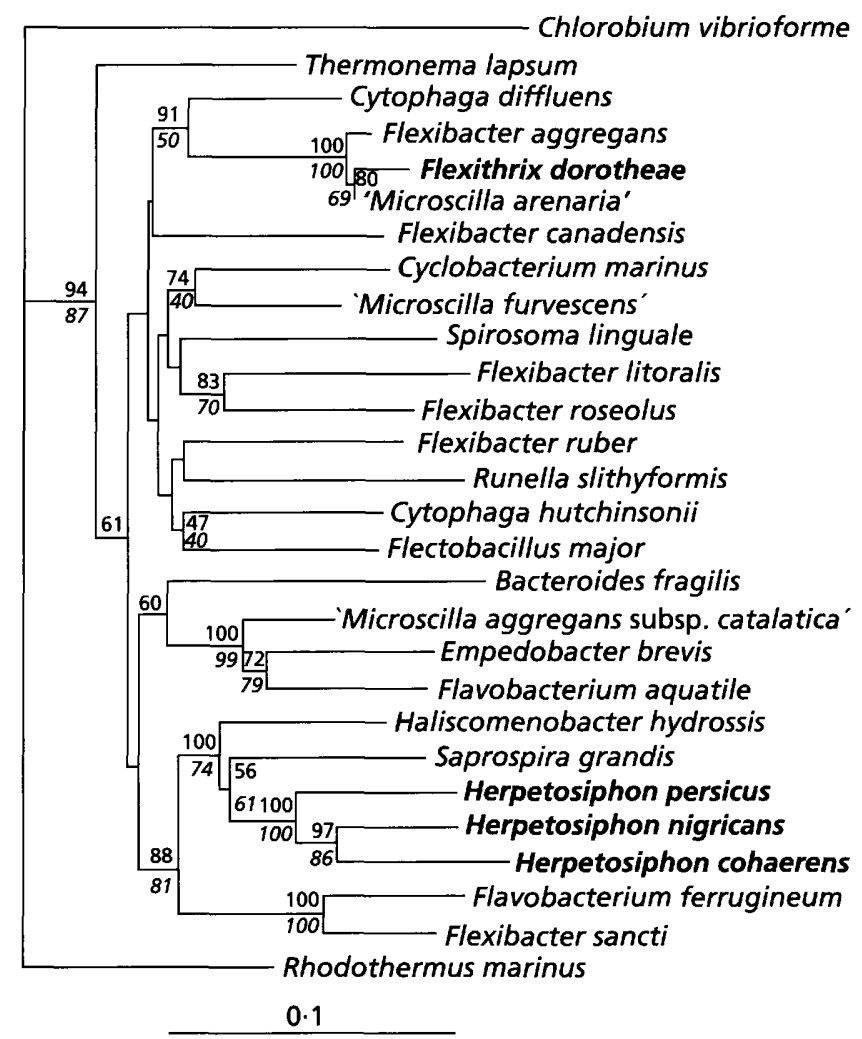

Fig. 2. Phylogenetic tree constructed by the neighbour-joining method showing the relationships of species of the genus Herpetosiphon and Flexithrix dorotheae in the FBC phylum. The sequence of Chlorobium vibrioforme was used as the outgroup. Bootstrap values of 100 analyses are shown at the top of the branching points for the neighbour-joining analysis and below (in italics) for the parsimony analysis. The scale bar represents 10 nucleotide substitutions per 100 nucleotides of 16S rDNA sequence.

clusion in the chemotaxonomic investigations may have provided an earlier insight into their relationship with the FBC bacteria. Likewise, determination of the phylogenetic position of the genus by 16S rRNA oligonucleotide catalogue analysis $(7,39,50)$ and $16 \mathrm{~S}$ rRNA sequences (30) was also confined to data from $H$. aurantiacus. These studies showed that the type species, and therefore the genus Herpetosiphon, is most closely related to Chloroflexus and Thermomicrobium. Like $H$. aurantiacus, the phototrophic gliding filamentous bacterium Chloroflexus may be thinly sheathed $(1,32)$ and has an unusual cell wall structure and composition. Both organisms lack LPS and contain a polysaccharide-peptidoglycan complex in which meso-diaminopimelic acid is replaced by $\mathrm{L}-$ ornithine $(11,12,36)$. Interestingly, Pierson \& Castenholtz in their description of Chloroflexus aurantiacus (32) observed that there was a striking morphological resemblance to some filamentous gliding flexibacteria such as Herpetosiphon which have similar DNA G $+\mathrm{C}$ composition $(20,24)$, but cautioned that this observation may be coincidental. It is probable that gliding motility and ensheathed morphology were early evolutionary traits and bacteria with these shared 
characteristics have now been observed in three evolutionary lineages, including the green non-sulfur bacteria, the FBC bacteria and the cyanobacteria.

The existence of a sheath in Herpetosiphon has been a matter of disagreement at least in part due to differences in interpretation of this morphological feature, possibly due to variation in growth conditions and methods of examination. Holt \& Lewin (10) included the presence of a sheath in the description of Herpetosiphon and confirmed this in the subsequent description of additional species (20). However, Reichenbach \& Golecki (37) disputed the presence of a classical sheath, but acknowledge the existence of an outer membranous structure they referred to as a 'sleeve'. Plausible arguments were mounted against the existence of a sheath (37), but some electron micrographs of thin sections of $H$. aurantiacus $(9,42)$ support the existence of a sheath surrounding the cells.

Following our finding that the marine species of Herpetosiphon belong to the FBC phylum, which includes many marine species of gliding bacteria, we considered it necessary to determine the relationship of these species with the other marine gliding sheathed bacterium, Flexithrix dorotheae, which was also isolated and described by Lewin (19) and for which a $16 \mathrm{~S}$ rRNA gene sequence was not available. The almost complete sequence was determined and phylogenetic analysis (Fig. 2) showed that this bacterium is in fact a member of the FBC phylum but does not group with the marine herpetosiphons. Rather, Flexithrix dorotheae clusters on a separate phylogenetic line with the marine species Flexibacter aggregans and 'Microscilla arenaria'. The 16S rDNA sequence of Flexithrix dorotheae has a similarity of $97.8 \%$ with that of its closest relative 'Microscilla arenaria' and $96 \%$ with Flexibacter aggregans over a sequence length of 1460 nucleotides. The sequences of Flexibacter aggregans and 'Microscilla arenaria' have a similarity of $98 \cdot 1 \%$. Recently, Nakagawa et al. (28) showed that Flexibacter aggregans is only distantly related to the type species of the genus Flexibacter, Flexibacter flexilis, and its taxonomic position is therefore uncertain. Because of the high 16S rRNA gene sequence similarities between Flexithrix dorotheae, Flexibacter aggregans, and 'Microscilla arenaria', DNA-DNA homology values will be required to determine their separate species status. It is possible that all three species belong to the one genus in which sheath formation is not a common characteristic. Lewin (19) proposed the genus Flexithrix to include the single species Flexithrix dorotheae characterized by flexuous cells capable of gliding but which formed falsely branched sheathed filaments. Whether the cultures consisted predominantly of ensheathed filaments or individual gliding cells was dependent on the cultural conditions $(19,34)$. This species was considered to be distinct from the marine ensheathed species Lewin assigned to the genus Herpetosiphon on the basis of sheathed morphology and substantially lower DNA base composition.
The close phylogenetic association of Flexithrix dorotheae with Flexibacter aggregans and 'Microscilla arenaria' highlights the persistent uncertainty which has beset the taxonomy of the members of the flexibacteria over a long period of time. Lewin (18) considered the flexibacteria to belong to four groups consisting of the Cytophaga-Microscilla-Flexibacter group, Saprospira, Flexithrix and Herpetosiphon. Previous phylogenetic research $(6,28,29,49,50,51)$ has shown that Cytophaga, Microscilla, Flexibacter and Saprospira belong to the FBC phylum, and the present research has confirmed this relationship for Flexithrix and the marine species of Herpetosiphon. Although Herpetosiphon in recent times has been excluded from taxonomic treatments of the Cytophagaceae in the Cytophagales $(33,35)$, presumably because of the phylogenetic relationship of the type species with Chloroflexus in the green non-sulfur bacteria, Flexithrix has continued to be included $(33,34,35)$ and the present findings justify this taxonomic judgement. Lewin's taxonomic reorganization of the flexibacteria was largely consistent with the findings of Fager's (4) recurrent group analysis of phenotypic characters, except that Lewin considered sheath formation to be such an important recognizable characteristic that it led him to separate strain QQ-3 (ATCC $23163^{\mathrm{T}}$ ) from group 3 of Fager's assemblage and describe it as Flexithrix dorotheae. Interestingly, in light of the present phylogentic study, the remaining strains in group 3 were named 'Microscilla aggregans' and included Flexibacter (Microscilla) aggregans strain NN-13 (= ATCC $23162^{\mathrm{T}}$ ) which we have shown is a close phylogenetic relative of Flexithrix dorotheae on the basis of $96 \% 16 \mathrm{~S}$ rRNA gene sequence similarity. The type strain of Flexithrix dorotheae is reported as not frequently producing a sheath and may then easily be confused with the flexibacters and microscillas, particularly in liquid culture (34). In its unsheathed form Flexithrix dorotheae closely resembles Microscilla (Flexibacter) aggregans (34), a relationship which is strongly supported by the present phylogenetic results. In our hands, we were also unable to observe a sheath in this strain and agree that its morphology is very similar to the unsheathed flexibacters. On the basis of a numerical analysis of a limited range of phenotypic traits determined by Lewin \& Lounsbury (21), Colwell (2) found insufficient support for the elevation of Flexithrix dorotheae, Microscilla species, and the marine Herpetosiphon species to generic rank and recommended that further study was required. The present study has provided phylogenetic evidence which supports the generic rank of Flexithrix, and also of the marine herpetosiphons, but has not considered the genus Microscilla, which has been addressed by others. The polyphyletic nature of the genus Herpetosiphon is not surprising given the frequent revelations on the phylogeny of the genera of the flexibacteria. Previous research has revealed the polyphyletic nature of the genera Flexibacter, Microscilla and Cytophaga, as well as showing their relationship with non-motile genera such Flavobacterium, Bacteroides and Halisco- 
Table 1. Differential characteristics of the genus Lewinella, other genera of gliding bacteria that form ensheathed filaments and Haliscomenobacter

Data compiled from references $6,7,9,16,19,20,23,24,26,27,30,32,34,36,47$ and this study. Abbreviations: + , positive; - , negative; + / - variable, FW, freshwater; M, marine; S, sewage; FBC, Flexibacter-Bacteroides-Cytophaga bacteria; GNS, green non-sulfur bacteria.

\begin{tabular}{|c|c|c|c|c|c|c|c|}
\hline Characteristic & Lewinella & Flexithrix & Haliscomenobacter & Herpetosiphon & Chloroflexus & Thiothrix & Thioploca \\
\hline Gliding motility & + & + & - & + & + & + & + \\
\hline Sheath & Unbranched & Falsely branched & Branched & Unbranched & Unbranched & Branched & Unbranched \\
\hline Holdfast & - & - & - & - & - & + & - \\
\hline Chemo-organotroph & + & + & + & + & $+1-$ & $+1-$ & \\
\hline Phototroph & - & - & - & - & + & - & - \\
\hline Mixotroph & - & - & - & - & - & $+1-$ & $+(?)$ \\
\hline Carotenoid pigments & + & + & + & + & + & & \\
\hline Bacteriochlorophyll & - & - & - & - & + & - & - \\
\hline$S$ deposits from $\mathrm{H}_{2} \mathrm{~S}$ & - & - & - & - & - & + & + \\
\hline Habitat & $\mathbf{M}$ & $\mathbf{M}$ & $\mathrm{FW}, \mathrm{S}$ & FW, S & FW & FW, S, M & FW, M \\
\hline Phylogenetic affiliation & FBC & FBC & FBC & GNS & GNS & & \\
\hline $\mathrm{G}+\mathrm{C}$ content $(\mathrm{mol} \%)$ & $45-53$ & 37 & 49 & 48 & $53-55$ & 52 & \\
\hline
\end{tabular}

menobacter in the FBC phylum $(6,28,29,31,49,50$, $51)$.

It is clear that the marine species currently assigned to the genus Herpetosiphon can not be considered to be members of this genus as they are only distantly related to the type species. Consequently, we propose that a new genus be described to accommodate them, for which we propose the name Lewinella gen. nov. No further phenotypic characterization of these species has been undertaken and the description of the species is based on data from previous publications $(9,20,24$, 36). Characteristics useful for the differentiation of the genus Lewinella from other gliding filamentous sheathed bacteria, and Haliscomenobacter are given in Table 1.

\section{Description of Lewinella gen. nov.}

Lewinella (Le.win.el'la. M.L. dim. ending -ella; M.L. fem. dim. n. Lewinella named after Professor Ralph Lewin, who first isolated these organisms).

Unbranched, flexible rods or filaments $0.5-1.5 \times 5$ $150 \mu \mathrm{m}$ or more (to several millimetres) consisting of individual cells $2-3 \mu \mathrm{m}$ long. Often ensheathed, although sheaths may be difficult to visualize. Filament breakage or cell lysis results in empty ends or spaces (necridia). Resting stages not known. Motile by gliding. Gram-negative. Produce orange or yellow carotenoid pigments. Chemo-organotrophs. Strict aerobes. Metabolism is respiratory, with molecular oxygen used as the terminal electron acceptor. Gelatin is hydrolysed, but not cellulose, chitin or starch. Require seawater for growth. Isolated from marine environments. Belongs to the FBC phylum. The DNA $\mathrm{G}+\mathrm{C}$ content is $44.9-53.1 \mathrm{~mol} \%$ (Bd) (24). The type species of the genus is Lewinella cohaerens. The species assigned to the genus Lewinella have not been studied extensively since their description by Lewin (20). The descriptions below are based on data and taxonomic considerations from Lewin (20), Mandel \& Lewin (24), Holt (9), Reichenbach (36) and the present study.

\section{Description of Lewinella cohaerens (Lewin 1970) comb. nov.}

Lewinella cohaerens (co.hae'rens. L. part. adj. cohaerens cohering, uniting together).

Unbranched, flexible, sheathed rods or filaments $0.7 \mu \mathrm{m}(1.0 \mu \mathrm{m}$ including sheath $) \times 60-150 \mu \mathrm{m}$ or longer. Cell masses have an orange pigment believed to be the carotenoid saproxanthin. Glucose and sucrose promote growth, but acetate, galactose, glycerol and lactate do not. Tryptone and glutamate but not nitrate serve as nitrogen sources. No acid is produced in litmus milk, but the milk is coagulated and the litmus is reduced. Tyrosine or dihydroxyphenylalanine are not degraded. No growth factors are required. Onehalf to double-strength seawater is required for growth. The DNA G+C content of the type strain is $44.9 \mathrm{~mol} \%(\mathrm{Bd})$. The type strain is strain II-2 $\left(=\right.$ ATCC $\left.23123^{\mathrm{T}}\right)$ isolated from beach sand, Biarritz, France.

\section{Description of Lewinella persica comb. nov.}

Lewinella persica [per'si.ca. L. adj. persica Persian (of fruit $=$ peach), i.e. peach-coloured].

Unbranched, flexible, sheathed rods or filaments $0.7 \mu \mathrm{m}(1.0 \mu \mathrm{m}$ including sheath $) \times 30-150 \mu \mathrm{m}$ or longer. Cell masses have an orange pigment believed to be the carotenoid saproxanthin. Glucose is a suitable carbon source. Sucrose and galactose promote growth, but acetate, glycerol and lactate do not. Tryptone, glutamate or nitrate serve as sole nitrogen sources. No acid is produced in litmus milk, but the milk is coagulated and the litmus is reduced. Tyrosine or dihydroxyphenylalanine are not degraded. No growth factors are required. One-half to double-strength seawater is required for growth. The DNA $G+C$ 
content of the type strain is $52.6 \mathrm{~mol} \%(\mathrm{Bd})$. The type strain is strain T-3 $\left(=\right.$ ATCC $\left.23167^{\mathrm{T}}\right)$ isolated from brown mud, Galway, Ireland.

\section{Description of Lewinella nigricans comb. nov.}

Lewinella nigricans (ni'gri.cans. L. part. adj. nigricans blackening).

Unbranched, flexible, sheathed rods or filaments $0.5 \mu \mathrm{m}(1.0 \mu \mathrm{m}$ including sheath $) \times 5-50 \mu \mathrm{m}$. Cell masses have a yellow pigment believed to be the carotenoid zeaxanthin. Glucose is a suitable carbon source. Sucrose and galactose promote growth, but acetate, glycerol and lactate do not. Casamino acids, tryptone, glutamate or nitrate serve as sole nitrogen sources. No acid is produced in litmus milk, but the milk is coagulated and digested, and the litmus is reduced. Tyrosine is degraded with the formation of a pigmented product. Dihydroxyphenylalanine is not degraded. No growth factors are required. One-half to double-strength seawater is required for growth. The DNA G $+\mathrm{C}$ content of the type strain is $53.1 \mathrm{~mol} \%$ (Bd). The type strain is strain SS-2 (= ATCC $\left.23147^{\mathrm{T}}\right)$ isolated from beach sand near Lagos, Nigeria.

\section{REFERENCES}

1. Castenholz, R. W. (1989). Genus Chloroflexus Pierson and Castenholz 1974. In Bergey's Manual of Systematic Bacteriology, vol. 3, pp. 1698-1702. Edited by J. T. Staley, M. P. Bryant, N. Pfennig \& J. G. Holt. Baltimore: Williams $\&$ Wilkins.

2. Colwell, R. (1969). Numerical taxonomy of the flexibacteria. $J$ Gen Microbiol 58, 207-215.

3. Deinema, M. H., Henstra, S. \& Werdmüller von Elgg, E. (1977). Structural and physiological characteristics of some sheathed bacteria. Antonie Leeuwenhoek 43, 19-29.

4. Fager, E. W. (1969). Recurrent group analysis in the classification of flexibacteria. J Gen Microbiol 58, 179-187.

5. Felsenstein, J. (1993). PHYLIP version 3.5c. University of Washington, Seattle.

6. Gherna, R. \& Woese, C. R. (1992). A partial phylogenetic analysis of the 'Flavobacter-Bacteroides' phylum: basis for taxonomic restructuring. Syst Appl Microbiol 15, 513-521.

7. Gibson, J., Ludwig, W., Stackebrandt, E. \& Woese, C. R. (1985). The phylogeny of the green photosynthetic bacteria: absence of a close relationship between Chlorobium and Chloroflexus. Syst Appl Microbiol 6, 152-156.

8. Godchaux, W. \& Leadbetter, E. R. (1983). Unusual sulfonolipids are characteristic of the Cytophaga-Flexibacter group. $J$ Bacteriol 153, 1238-1246.

9. Holt, J. G. (1989). Genus Herpetosiphon Holt and Lewin, 1965. In Bergey's Manual of Systematic Bacteriology, vol. 3, pp. 2136-2138. Edited by J. T. Staley, M. P. Bryant, N. Pfennig \& J. G. Holt Baltimore: Williams \& Wilkins.

10. Holt, J. G. \& Lewin, R. A. (1968). Herpetosiphon aurantiacus gen, et sp. n., a new filamentous gliding organism. $J$ Bacteriol 95, 2407-2408.

11. Jürgens, U. J., Meissner, J., Fischer, U., König, W. A. \& Weckesser, J. (1987). Ornithine as a constituent of the peptidoglycan of Chloroflexus aurantiacus, diaminopimelic acid in that of Chlorobium vibrioforme f. thiosulfatophilum. Arch Microbiol 148, 72-76.

12. Jürgens, U. J., Meissner, J., Reichenbach, H. \& Weckesser, J. (1989). L-Ornithine containing peptidoglycan-polysaccharide complex from the cell wall of the gliding bacterium Herpetosiphon aurantiacus. FEMS Microbiol Lett 60 , 247-250.

13. Jukes, T. H. \& Cantor, C. R. (1969). Evolution of protein molecules. In Mammalian Protein Metabolism, pp. 21-132. Edited by H. N. Munro. New York: Academic Press.

14. Kleinig, H. \& Reichenbach, H. (1977). Carotenoid glucosides and menaquinones from the gliding bacterium Herpetosiphon giganteus $\mathrm{Hp}$ a2. Arch Microbiol 112, 307-310.

15. Lane, D. J. (1991). 16S/23S rRNA sequencing. In Nucleic Acid Techniques in Bacterial Systematics, pp. 115-175. Edited by E. Stackebrandt \& M. Goodfellow. Chichester: Wiley.

16. Larkin, J. M. (1989). Genus II. Thiothrix Winogradsky 1888. In Bergey's Manual of Systematic Bacteriology, vol. 3, pp. 2098-2101. Edited by J. T. Staley, M. P. Bryant, N. Pfennig \& J. G. Holt. Baltimore: Williams \& Wilkins.

17. Leadbetter, E. R. (1974). Order II. Cytophagales. In Bergey's Manual of Determinative Bacteriology, 8th edn, pp. 99-101. Edited by R. E. Buchanan \& N. E. Gibbons. Baltimore: Williams \& Wilkins.

18. Lewin, R. A. (1969). A classification of flexibacteria. $J$ Gen Microbiol 58, 189-206.

19. Lewin, R. A. (1970). Flexithrix dorotheae gen. et sp. nov. (Flexibacterales); and suggestions for reclassifying sheathed bacteria. Can J Microbiol 16, 511-515.

20. Lewin, R. A. (1970). New Herpetosiphon species (Flexibacterales). Can J Microbiol 16, 517-520.

21. Lewin, R. A. \& Lounsbery, D. M. (1969). Isolation, cultivation and characterization of flexibacteria. $J$ Gen Microbiol 58, 145-170.

22. Maidak, B. L., Olsen, G. J., Larsen, N., Overbeek, R., McCaughey, M. J. \& Woese, C. R. (1997). The RDP (Ribosomal Database Project). Nucleic Acids Res 25, 109-111.

23. Maier, S. (1989). Genus III. Thioploca Lauterborn 1907. In Bergey's Manual of Systematic Bacteriology, vol. 3, pp. 2101-2105. Edited by J. T. Staley, M. P. Bryant, N. Pfennig \& J. G. Holt. Baltimore: Williams \& Wilkins.

24. Mandel, M. \& Lewin, R. A. (1969). Deoxyribonucleic acid base composition of flexibacteria. J Gen Microbiol $\mathbf{5 8}$, 171-178.

25. Moore, W. E. C. \& Moore, L. V. H. (1992). Index of the Bacterial and Yeast Nomenclatural Changes. Washington, DC: American Society for Microbiology.

26. Mulder, E. G. (1989). Genus Haliscomenobacter van Veen, van der Kooy, Geuze and van der Vlies 1973. In Bergey's Manual of Systematic Bacteriology, vol. 3, pp. 2003-2004. Edited by J. T. Staley, M. P. Bryant, N. Pfennig \& J. G. Holt. Baltimore: Williams \& Wilkins.

27. Mulder, E. G. \& Deinema, M. H. (1992). The genus Haliscomenobacter. In The Prokaryotes, 2nd edn, vol. 4, pp. 3688-3690. Edited by A. Balows, H. G. Trüper, M. Dworkin, W. Harder \& K.-H. Schleifer. New York: Springer.

28. Nakagawa, Y., Hamana, K., Sakane, T. \& Yamasato, K. (1997). Reclassification of Cytophaga aprica (Lewin 1969) Reichenbach 1989 in Flammeovirga gen. nov. as Flammeovirga 
aprica comb. nov. and of Cytophaga diffluens (ex Stanier 1940; emend Lewin 1969) Reichenbach 1989 in Persicobacter gen. nov. as Persicobacter diffluens comb. nov. Int J Syst Bacteriol 47, 220-223.

29. Nakagawa, Y. \& Yamasato, K. (1993). Phylogenetic diversity of the genus Cytophaga revealed by $16 \mathrm{~S}$ rRNA sequencing and menaquinone analysis. J Gen Microbiol 139, 1155-1161.

30. Oyaizu, H., Debrunner-Vossbrinck, B., Mandelco, L., Studier, J. A. \& Woese, C. R. (1987). The green non-sulfur bacteria: a deep branching in the eubacterial line of descent. Syst Appl Microbiol 9, 47-53.

31. Paster, B. J., Ludwig, W., Weisburg, W. G., Stackebrandt, E., Hespell, R. B., Hahn, C. M., Reichenbach, H., Stetter, K. O. \& Woese, C. R. (1985). A phylogenetic grouping of the bacteroides, cytophagas, and certain flavobacteria. Syst Appl Microbiol 6, $34-42$.

32. Pierson, B. K. \& Castenholtz, R. W. (1974). A phototrophic gliding filamentous bacterium of hot springs, Chloroflexus aurantiacus, gen. and sp. nov. Arch Microbiol 100, 5-24.

33. Reichenbach, H. (1989). Family Cytophagaceae Stanier 1940. In Bergey's Manual of Systematic Bacteriology, vol. 3, pp. 2013-2050. Edited by J. T. Staley, M. P. Bryant, N. Pfennig \& J. G. Holt. Baltimore: Williams \& Wilkins.

34. Reichenbach, H. (1989). Genus III Flexithrix Lewin 1970. In Bergey's Manual of Systematic Bacteriology, vol. 3, pp. 2058-2060. Edited by J. T. Staley, M. P. Bryant, N. Pfennig \& J. G. Holt. Baltimore: Williams \& Wilkins.

35. Reichenbach, H. (1992). The order Cytophagales. In The Prokaryotes, 2nd edn, vol. 4, pp. 3631-3675. Edited by A. Balows, H. G. Trüper, M. Dworkin, W. Harder \& K.-H. Schleifer. New York: Springer.

36. Reichenbach, H. (1992). The genus Herpetosiphon. In The Prokaryotes, 2nd edn, vol. 4, pp. 3785-3805. Edited by A. Balows, H. G. Trüper, M. Dworkin, W. Harder \& K.-H. Schleifer. New York: Springer.

37. Reichenbach, H. \& Golecki, J. R. (1975). The fine structure of Herpetosiphon, and a note on the taxonomy of the genus. Arch Mirobiol 102, 281-291.

38. Reichenbach, H., Beyer, P. \& Kleinig, H. (1978). The pigments of the gliding bacterium Herpetosiphon giganteus. FEMS Microbiol Lett 3, 155-156.

39. Reichenbach, H., Ludwig, W. \& Stackebrandt, E. (1986). Lack of relationship between gliding cyanobacteria and filamentous gliding heterotrophic eubacteria: comparison of 16S rRNA catalogues of Spirulina, Saprospira, Vitreoscilla,
Leucothrix, and Herpetosiphon. Arch Microbiol 145, 391-395.

40. Saitou, N. \& Nei, M. (1987). The neighbor-joining method: a new method for constructing phylogenetic trees. Mol Biol Evol 4, 406-425.

41. Skerman, V. B. D., McGowan, V. \& Sneath, P. H. A. (editors) (1989). Approved Lists of Bacterial Names. Washington, DC: American Society for Microbiology.

42. Skerman, V. B. D., Quinn, G. R., Sly, L. I. \& Hardy, J. V. (1977). Sheath formation by strains of Herpetosiphon species. Int $J$ Syst Bacteriol 27, 274-278.

43. Soriano, S. \& Lewin, R. A. (1965). Gliding microbes: some taxonomic reconsiderations. Antonie Leeuwenhoek 31, 66-80.

44. Stackebrandt, E. \& Charfreitag, O. (1990). Partial 16S rRNA primary structure of five Actinomyces species: phylogenetic implications and development of an Actinomyces israeliispecific oligonucleotide probe. J Gen Microbiol 136, 37-43.

45. Stackebrandt, E. \& Goebel, B. (1994). Taxonomic note: a place for DNA-DNA reassociation and 16S rRNA sequence analysis in the present species definition in bacteriology. Int $J$ Syst Bacteriol 44, 846-849.

46. Taghavi, M., Hayward, C., Sly, L. I. \& Fegan, M. (1996). Analysis of the phylogenetic relationships of strains of Burkholderia solanacearum, Pseudomonas syzygii, and the blood disease bacterium of banana based on 16S rRNA gene sequences. Int $J$ Syst Bacteriol 46, 10-15.

47. van Veen, W. L., van der Kooij, D., Geuze, E. C. W. A. \& van der Vlies, A. W. (1973). Investigations on the sheathed bacterium Haliscomenobacter hydrossis gen. n., sp. n., isolated from activated sludge. Antonie Leeuwenhoek 39, 207-216.

48. Wayne, L. G., Brenner, D. J., Colwell, R. R. \& 9 other authors (1987). International Committee on Systematic Bacteriology. Report of the ad hoc committee on reconciliation of approaches to bacterial systematics. Int J Syst Bacteriol 37, $463-464$.

49. Weisburg, W. G., Oyaizu, Y., Oyaizu, H. \& Woese, C. R. (1985). Natural relationship between bacteroides and flavobacteria. J Bacteriol 164, 230-236.

50. Woese, C. R., Stackebrandt, E., Macke, R. J. \& Fox, G. E. (1985). A phylogenetic definition of the major eubacterial taxa. Syst Appl Microbiol 6, 143-151.

51. Woese, C. R., Yang, D., Mandelco, L. \& Stetter, K. O. (1990). The flexibacter-flavobacter connection. Syst Appl Microbiol 13, 161-165. 